\title{
Out of School Learning Environments in Social Studies Education: A Phenomenological Research with Teacher Candidates
}

\author{
Ersin TOPÇU ${ }^{1}$ \\ ${ }^{1}$ Faculty of Education, Kastamonu Üniversity, Turkey \\ Correspondence: Ersin TOPÇU, Faculty of Education, Kastamonu Üniversity, Turkey. E-mail: \\ ertopcu@gmail.com
}

Received: February 8, 2017

Accepted: March 9, 2017 Online Published: June 27, 2017

doi:10.5539/ies.v10n7p126

URL: https://doi.org/10.5539/ies.v10n7p126

\begin{abstract}
In this study, it was aimed to determine the remarks of teacher candidates on the place and importance of out of school learning environments in Social Studies education. Phenomenological method, which is one of the qualitative research designs, was used in this study. The work group of the study consists of 73 teacher candidates who conduct out of school activities ( 43 of them are Social Studies teacher candidates and 31 of them are Classroom teacher candidates). Semi structured interview form was used as data collection tool. Activity phase of the study was conducted in museums, Islamic-Ottoman social complexes, castles and historic mosques in Kastamonu, Sakarya, Kars and Ereğli (a district of Zonguldak). Gathered data of the study was examined by using content analysis method, and it was presented with cause and effect relation. When results of the study were evaluated, it was concluded that teacher candidates believe that out of school learning activities embody the knowledge and increase memorability by integrating learning into living. Besides, according to teacher candidates, there are many obstacles ahead of out of school activities particularly economic reasons and reluctance of teachers and the structure/content of Social Studies lesson is very suitable for such activities.
\end{abstract}

Keywords: classroom teacher candidate, out-of-school learning environment, social studies lesson, social studies teacher candidate

\section{Introduction}

Outdoor education is a multidimensional process, which presents study of constructed learning activities in outside places as community and natural settings (Bunting, 2006). This process is continual, and shows itself in the shape of the integration of life and learning in all levels (Ford, 1986).

Out of school learning of which institutional framework was defined by Comenius, Locke, Rousseau, Pestalozzi, Froebel and Dewey in 18 and $19^{\text {th }}$ centuries can be also explained as integration of school and the environment which is now an obligation by maintaining the suitable subjects of the courses out of the school in a more concrete way with different materials, experiences etc. (Okur-Berberoğlu \& Uygun, 2013; (Şimşek \& Kaymakçı, 2015). The change and accumulation of the knowledge is attempted to be managed in schools but these institutions giving formal education fail to catch up with these changes and fall behind. Today, those who want to access to the knowledge have to fight against environmental factors along with the changes. That there are several facilities (smart phone/Internet etc.) a student can waste time, enjoy himself and thus giving more attention within the school, out of the school and also during the course makes the learning at school harder. It is getting harder and harder to draw the attention to the subject covered while the student has the ability to surf online, contact his oversea friend in an indoor environment such as school or classroom. The advances in technology have many benefits and make our lives easier but on the other hand it is also an undeniable fact that it causes students to be antisocial individuals with the social media (Facebook etc.) when it is used unreasonably (Barnes and Laird, 2014; Dubow, Huesmann, \& Greenwood, 2006; Goessl, 2010; Rosen, 2011; Stollak Vandenberg, Zeni, \& Scribner, 2014).

There are many researches carried out on the benefits of out of school learning practices to education. With this learning method, students go beyond the limits and physically fill in the eternity in their minds partly by visiting the places such as museums, art galleries etc. Thus, they have fun and the knowledge they acquire likely to have become permanent. The main purpose of the activities is to make the students engage the process actively and thus enable effective learning and contribute to the development of cognitive, affective, and psychomotor skills 
of the students (Tatar \& Bagriyanik, 2012; Turkmen, 2010; Lakin, 2006).

Considering the researches above mentioned, out of school learning is commonly accepted as beneficial and encouraged especially in developed countries (Sahenk-Erkan, 2013; Taylor, Power \& Rees, 2010). In Turkey, curriculum of social sciences course involves some aim and skills, which require the practice of out of school activities. Most of the skills that students are aimed to acquire such as observation, perception of the place, understanding of change and continuity, and social engagement involved in the 2005 curriculum of Social Sciences requires out of school learning. For example within the framework of the concept of museum knowledge in the program of $6^{\text {th }}$ and $7^{\text {th }}$ grades, students are aimed to realize some skills which are hard to realize in class and have the chance to encounter the objects in daily life by giving courses in all settings involving the natural and cultural assets. Additionally, skills to understand, protect, assess and interpret cultural assets, historical artifacts help them to develop perception of time and place, embrace inter cultural understanding, arise visual awareness to their environment, make connection between past, present and future, have archiving skills, and raise socialized individuals are among other aims.

Moreover these kinds of settings (museums, monuments, historical artifacts) help students empathize history and improve their historical thinking skills by enabling them experience and connect with people from past since they give the students the chances to find out new learning methods and work actively with concrete evidence and affected the attitude of students towards Social Sciences course, contributing to the affective and cognitive skills of the students (Akyuz, 2009; Hooper-Greenhil, 1999; Marcus, 2007; Tahiroglu, 2012; Demirboğa, 2010; Ermis, 2010; Filiz, 2010; Bozdogan \& Yalcın, 2006; Cengelci, 2013; Simsek \& Kaymakci, 2015). Other conclusions of the studies include museums should be involved in course program not to cover a History subject monotonously, to contribute the permanent learning and for identity formation (Basu \& Coleman, 2010; Yilmaz \& Eguz, 2015). Objects from different cultures and the fact that the similar objects are also being exhibited in different museums around the world help students to be aware of the cultural heritage and inter cultural interaction (Karadeniz \& Okvuran, 2004; Coskun-Keskin \& Kaplan, 2012).

While Ministry of National Education (MEB) encourage the out of school learning by adding some aims and skills in curriculum, Faculties of Education also have the setting to include these practices in their curriculum. For example, the content of the courses teacher candidates attend in social sciences and primary school teaching undergraduate programs is compatible with the curriculum of MEB. In the curriculum of the compulsory course "Special Teaching Methods II" that students in the Department of Social Sciences Teaching attend in $6^{\text {th }}$ term, the necessity of practices such as using the computer and Internet, improvement of the graphic and table reading skills, use of the visual materials and documents, covering of History of Republic and Ataturk, oral history activities, benefit from special days and weeks, involving the current issues, planning of the environmental studies, museum knowledge, question asking and its methods, contemporary assessment are highly emphasized. Similarly, the explanation in the curriculum of "Social Sciences Teaching" which is compulsory for primary school teaching students in $6^{\text {th }}$ term suggests using the strategies, methods, techniques and materials and related examples about the social sciences. These attempts enable the setting suitable for out of school practices in undergraduate programs as well.

When taking all of those in consideration, it is a necessity for the teacher to take advantage of the out of school learning both for himself and the students to enjoy the lessons and the knowledge to become permanent since the aim of the course of Social Sciences is to make individuals efficient and social citizens. However, when the studies are classified one can see that there is not enough study about the candidate teachers. The studies mostly cover the subject in two ways.

One of them is about the views of the sample group on those practices. This one is also divided into two groups: studies containing teacher views and studies containing student views. Some of the studies on teacher include the ones by Aladag, Akkaya, and Şensöz (2014), Aytekin (2006), Ata (2012), Cavus et al. (2013), Cengelci (2013), Cepni and Aydın (2015), Karakus, Aksoy, and Gündüz (2012), and Oner (2015). Other studies on student views include the ones by Culha (2006), Donmez (2009), Ermis (2010), Karadeniz and Ata (2013), Yapici (1995), Yilmaz and Seker (2011).

The other one is about the effects of these practices/methods on learning, success or attitudes of the students. These studies analyze not only the out of school practice methods but also their impact on success. This group can be divided into two categories as well. Some of the studies analyzing the types/methods of out of school practices include the ones by Aktekin (2010), Avci-Akcali and Aslan (2012), Coskun-Keskin and Kaplan (2012), Danacioglu (2001), Durmus (2007), Meydan (2009), Ozgen (2011), Safran and Ata (1998), Sari (2007), and Yesilbursa (2008). Some of the studies analyzing the success, skills and attitudes of the students include the ones 
by Demirboga (2010), Demirci (2009), Ertas (2012), Isik (2008), Meydan and Akkus (2014), Sari (2007), Tosun (2009), Tunc-Sahin (2011), Utku (2008), Ustaoglu (2012), Yildirim and Tahiroglu (2012).

As a result, when the studies above-mentioned (the list can be longer) are analyzed, one can see that the methods and contributions of these practices, the views of the students and the teachers were studied but the candidate teachers were neglected. However, the views of the future teachers about these practices, which are important for social sciences, the way of education they encountered in undergraduate program, can affect their attitude towards these practices when they become teachers. Moreover, the data collected at the end of the studies would give ideas to some extent about the undergraduate dimension of the out of school learning in Turkey and the views of the candidate teachers both for the researchers in Turkey and abroad. Thus, it is significant to know the views of the new teachers (social sciences and primary school) about the benefits and necessity of these practices. In this context, the aim of this research is to find out the views of the candidate social sciences and primary school (Note 1). Teachers on the benefits and significance of the out of school practices within the social sciences teaching in terms of the activities they should carry out.

\section{Method}

In this qualitative research, phenomenological pattern was used in accordance with the aim and logic of the study. The reason behind the selection of this pattern is to find out the views of the participants about the facts they are familiar with and in compliance with the aim of the study (Yildirim \& Simsek, 2005).

\subsection{Work Group}

The work group of this study consists of the candidate teachers at 3rd grade in the departments of Social Sciences Teaching and Primary School Teaching at Universities of Kastamonu, Sakarya, Bulent Ecevit. The work group is determined by purposeful sampling model. This model makes it possible to study deeper the situations with rich data (Balci, 2004). Therefore variation sampling method was preferred out of the all purposeful sampling models. It is aimed to find out the different dimensions (if available) of the problem under the light of the various data collected (Yildirim \& Simsek, 2005). General information about the participants is given in the table below:

Table 1. General Information about the Participants

\begin{tabular}{|c|c|c|c|c|c|c|c|c|c|c|}
\hline \multirow{3}{*}{\multicolumn{2}{|c|}{ University }} & \multirow{2}{*}{\multicolumn{2}{|c|}{$\begin{array}{c}\begin{array}{c}\text { Kastamonu } \\
\text { University }\end{array} \\
\text { Gender }\end{array}$}} & \multicolumn{2}{|c|}{ Sakarya University } & \multicolumn{2}{|c|}{ Kafkas University } & \multicolumn{2}{|c|}{$\begin{array}{c}\text { Bülent Ecevit } \\
\text { University }\end{array}$} & \multirow{3}{*}{ Total } \\
\hline & & & & \multicolumn{2}{|c|}{ Gender } & \multicolumn{2}{|c|}{ Gender } & \multicolumn{2}{|c|}{ Gender } & \\
\hline & & Female & Male & Female & Male & Female & Male & Female & Male & \\
\hline \multirow{3}{*}{ Department } & Social Studies & 7 & 6 & 7 & 4 & 4 & 6 & 5 & 3 & 42 \\
\hline & Classroom & 5 & 2 & 5 & 3 & 2 & 4 & 6 & 4 & 31 \\
\hline & Total & 12 & 8 & 12 & 7 & 6 & 10 & 11 & 7 & 73 \\
\hline
\end{tabular}

The content of the courses, which candidate teachers attended, was an important factor in selection of the participants. In the curriculum of the compulsory course "Special Teaching Methods II" that students in the Department of Social Sciences Teaching attend in 7th term, and "Social Sciences Teaching" which is compulsory for primary school teaching students in $6^{\text {th }}$ term suggests using the strategies, methods, techniques and materials and related examples about the social sciences.

\subsection{Data Collection Tool and its Improvement}

Semi-structured interview was used as a data collection tool. With this method, the answers of the participants can be compared. It is also possible to see their personal viewpoints, complexity of their experiences and the terminology used by them, and then ask for more details if necessary (Patton, 2014). After theoretical framework of the study was created, semi-structured interview form were prepared based on the views of the specialists in Social Sciences. While the form was being prepared, literature about the social science teaching and out of school learning settings was reviewed, and then 9 questions were prepared. Later, feedback from 6 social science specialists from 4 universities reshaped the form. This updated form was applied to 15 candidate teachers as a pilot scheme and then the numbers of questions were reduced to 5 .

\subsection{Collection of Data}

When the final versions of the questions were ready, the participants were asked to answer the personal questions on the interview form. During the interview, participants were encouraged to feel comfortable about explaining 
their views on out of school learning in Social Science course. Moreover, the participants were asked to give detailed information to collect more data. The candidate teachers of Social Sciences filled the form in the first week of November, fall term of 2014-2015 academic year; on the other hand, the candidate teachers of Primary School filled the form in the spring term of the same academic year, second week of May. The activities took place in the same period for both of the group. In the first week, theoretical and practical activities were carried out in museums, social complexes, castles and historical mosques in the residing city. In the second week; on the other hand, data collected from candidate teachers through semi-structured forms.

\subsection{Analysis of Data}

Gathered data of the study was examined by using content analysis method, and it was presented with cause and effect relation. The main reason of preferring this method is to reach relations and concepts that can explain gathered data in detail. Data, which is summarized and interpreted with descriptive analysis, is examined further with content analysis, and concepts and themes that cannot be noticed with descriptive analysis can be found because of using content analysis (Yıldırım \& Şimşek, 2005). Within this scope, categories were formed by paying attention to relations among gathered data of the study, and themes were formed by interpreting these categories. By directly quoting the remarks of participants gathered during the study, it was aimed to gain validity. For the sake of gaining credibility, applications were performed in accordance with triangulation technique. Besides to increase the credibility, gathered data was analyzed by two different social studies education specialist in accordance with multiple analyzer triangulation, and results were compared (Patton, 2014; Miles \& Huberman, 2015). Besides, gathered data was shared with participants for revision. The coding of data was carried out two more times by the same researcher in different times. To eliminate the contradictions occur during the revision of coding, the opinions of two social studies education specialist were received. Herewith the coherency analysis of the study was made. The last step for the credibility of the study was to use the reliability of measurement formula of Stemler (2001). For this, this formula of Miles and Huberman (2015) was used, and reliability was found as $91 \%$, and the study was found reliable.

\section{Findings and Comments}

-Definitions about out of School Learning environment:

Table 2. Remarks of teacher candidates on concepts they use to describe out of school learning environment

\begin{tabular}{llcc}
\hline Category & Code & Frequency $(f)$ & Rate $(\%)$ \\
\hline \multirow{5}{*}{ Definitions } & Museum trips & 58 & 34.9 \\
& Historical place visits & 45 & 27.1 \\
& Garden (school garden etc.) & 18 & 10.8 \\
& Geographical places (mountain, forest, etc.) & 17 & 10.2 \\
& Religious places (mosque, church etc.) & 15 & 9 \\
& Zoo & 5 & 3 \\
& Other: (Library, hospital, senior center, NGO's etc.) & 8 & 4.8 \\
& Total & 166 & 100 \\
\hline
\end{tabular}

Answers were evaluated in Table 2 in general. According to these, it is seen that teacher candidates use different descriptions for out of school learning practices. The most used concepts are in order of; museum trips (34.9\%) and historical place visits $(27.1 \%)$, school garden (10.8\%), geographical place visits $(10.2 \%)$, religious place visits $(9 \%)$ and zoo visits (3\%). In addition to these, hospitals, senior centers, NGOs etc. (4.8\%) are also places that teacher candidates think of as out of school learning environment.

When the answers were evaluated, it was seen that teacher candidates consider out of school learning on trip and observation basis. In addition to the intended academic knowledge by the Ministry of National Education that they contain, museums are suitable places for students to acquire many skills and value. With the project of "the Biggest Museum of the World: Turkey", Ministry of Culture tries to prove how rich our country from this aspect, and according to their data; Turkey has 187 public, and 183 private in total 370 museums. Because of that these compelling museums are almost in every city, and easy to access with museum cards, they are the first place that teacher candidates think of when they consider out of school learning environments. Teacher candidate K3 made this statement about "museum trips" which is the most common description with 34,9 percent.

-"When we say out of school learning environment, museum trips are the first thing that comes to my mind. Anyway we only made that at the university." 
The second most frequently referred description after museums by candidate teachers was "historical place visits" with $27.1 \%$. These places, which is also a subject to above mentioned ministry project, can be find in almost every city of Turkey, and as one of the most important values of cultural heritage so to speak they share task with museums. This region, which draws millions of foreign tourists every year, with its 12500 years old civilization history, has historical places (museums /archeological sites- 75 of them in Wold Cultural Heritage list) spread almost all around the country, and using these historical places in education of social studies subjects is an implicit necessity. These places are very special areas in which past and today come together, and it may be said that they are far more organic than museums. It is also true that such places - such as Rumelian fortress, trenches in Gallipoli, which may be defined as Cultural heritage site, have the power to make students feel different emotions, and lead them to embrace this culture and country. Hence, it is not a coincidence for teacher candidates to refer historical places as the most important second out of school environment. K17 made this statement;

-"I can mostly think of visiting historical places. Because both there are a lot of historical places in our country and these places have a strong emotional affect in people."

The third most frequently referred description by candidate teachers was "using school garden" with $10.8 \%$. Using school garden is the easiest activity, and it is not only used in Turkey. It is natural for school gardens to be one of the most frequently used areas because of its being safe, free of cost, and that it does not require a permit. K6, one of the teacher candidates, made this statement about using school gardens as out of school environment;

-"When we talk about out of school learning, first thing comes to my mind is school garden as we used while studying primary school. It is both free of cost, and easy, and riskless. In my opinion, it is always better than teaching a lesson in a classroom "

Although it has these advantages, teacher candidates put "school garden" to the third rank. One of the reasons of this may be that teacher candidates expect more from the term of out of school, and because of that school garden is still in the borders of school, it does not give the "out of school" feeling to them (K6, K9, K26, K43, $\mathrm{K} 44, \mathrm{~K} 52$, K63, K67, K71, K72, K73). Some statements that were made in this direction were given below;

$\mathrm{K} 44$;

-"The first thing came to my mind was museums. Although it is not possible to go to museums always in everywhere. For example, there are students at villages or small cities. That is why school garden is the cheapest, easiest choice, but you feel like you do not go to another place when you are still in the borders of the school.

K71;

-"When you say out of school, it means places not in the school. For example; museums. As long as we go out of the school, it is okay."

K6;

"In my opinion out of school can be museums, historical places. I mean it can be every place that can make students feel like a different place than school."

-Suitability of Social Studies lesson to Out of School Learning environments

Table 3a. Remarks of teacher candidates on the suitability of Social Studies lesson to Out of School learning environments

\begin{tabular}{lccc}
\hline Category & Code & Frequency $(f)$ & Rate $(\%)$ \\
\hline \multirow{4}{*}{ Suitability } & Suitable & 73 & 100 \\
& Unsuitable & -- & -- \\
& Total & 73 & 100 \\
\hline
\end{tabular}

Answers were evaluated in Table 3a in general. According to this, all of the teacher candidates $(\% 100)$ stated that out of school learning practices are suitable for Social Studies lesson. Some of the statements of teacher candidates who made this kind of explanations were given below;

K10;

-"There is a lot of need for this kind of activities for the structure, subjects, and objectives of Social 
Studies."

$\mathrm{K} 52$;

-"It is probably easier to find an out of school practice environment for Social Studies lesson, in which there are subjects of history and geography, more than every other lesson. Because, almost in every place in our country, there are old mosques, caravansary, fountains or any other historical artifacts. And this makes it easier to implement this technique for Social Studies."

K69;

-"I think the most suitable lesson is Social Studies. Because there is a suitable place for almost all subjects. If you want to socialize the students, you need to show them the life."

Subjects of Social Studies lesson, in which there are subjects of history, geography and citizenship accepted as basic disciplines, are too linked to social life to only study in four walls. This lesson basically invites students and teachers to outside of the school. Social Studies lesson, for which there are physical objects for almost all of its subjects, is seen very suitable for out of school learning activities. Teacher candidate K16 made a really descriptive and interesting statement about this;

-"Social Studies lesson is pretty obvious as you can understand from also its name. Thereby you should not avoid social environments. Everything about our subjects is outside. In fact, I think Social Studies lesson should always be taught out of school in different environments. Lesson in classroom should be an exception for rainy and cold weather-:."

With this answer, teacher candidate almost implies that not out of school but inside of school social studies education should be researched. Yet although the idea of making the environment of this lesson out of school is physically impossible, it is not contradictory for the structure-logic of the lesson.

Table 3b. Remarks of teacher candidates on the reasons of the suitability of out of school learning practices to Social Studies lesson

\begin{tabular}{llcc}
\hline Category & Code & Frequency $(f)$ & Rate $(\%)$ \\
\hline \multirow{4}{*}{ Reasons } & Learning through experience & 83 & 47.2 \\
& Embodying the subject and making it permanent & 37 & 21 \\
& Preparing for life & 23 & 13 \\
& Making it fun & 18 & 10.2 \\
& Developing multiple point of views & 12 & 6.8 \\
& Interaction with environment and people & 3 & 1.7 \\
& Total & 176 & 100 \\
\hline
\end{tabular}

Answers were evaluated in Table $3 b$ in general. According to this, it is seen that teacher candidates state that out of school learning practices are beneficial for learning through experience (47.2\%), embodying the subject partially and making it permanent because students feel themselves like in real life (21\%), increasing the qualification of students for life (13\%), saving the lesson from the point that it just requires memorizing and making it fun10.2), developing multiple point of views (6.8\%), and increasing interaction with environment and people (1.7\%).

According to this, it is seen that teacher candidates gave directly related answers to the structure of these activities as reasons for the suitability of out of school learning practices to Social Studies lesson. No matter which subject or lesson, when students are out of school, it is always a matter of learning through experience. Statements made by teacher candidates accordingly to this subject were given below;

$\mathrm{K} 51$;

-"Yes, subject of Social Studies are directly related to social life. That is why student finds an opportunity to learn through experience for example; by visiting governor, kaimakam, village headmen for citizenship subjects, or visiting malls or supermarkets for the subjects related to consumption.

K69;

"When the subject is Gallipoli War, instead of teaching it in the classroom, a trip can be organized, and students can have an experience that they can never forget by experiencing that atmosphere and gain knowledge about the subject. 
If students see the places (ruins, work of arts, historical places), which are mentioned in textbooks, in real life, they will be directly in the event and not just become an audience but they will become a leading role, and this will increase the permanence of learning inevitably. Because with this, the reality of things, which are abstract on paper or just pictures, now become physical and visible. When a student visit Haghia Sophia mosque, which has the biggest dome in the world, it will be different than seeing it just on a book, TV or internet or seeing the battlefield, trenches of Canakkale by going there and feeling the horror of the war in its atmosphere may have a great impact on the embodiment of the subject by the student, and making it permanent about the subject that were taught to him/her in lessons. Hence, teacher candidates stated that these applications partially lead to embodiment of subjects and lead to a more permanent learning regarding to learning through experience. This situation, which makes students to feel in real life, is the second most frequently referred reason with $21 \%$. Statement made by teacher candidates K4 accordingly to this subject was given below;

-'Yes, because of that objectified versions of subjects (castle, mountain etc.) exist in real life, students learn through experience and knowledge becomes permanent."

Such implementations may cause students to be prepared to real life better by seeing real/physical versions of lesson subjects. Yet concepts such as governor, mayor or mukhtar become real and maybe student can find an opportunity to directly meet a governor or maybe a mayor. Thus, students have the opportunity to learn/see how things work in real life at first hand, they will know that life better, and it may become possible for them to prepare life better. Briefly, as 14.5 percent of teacher candidates stated it will increase their qualifications for life. Statement made by K43, one of the teacher candidates accordingly to this subject was given below;

-"I think it is really suitable. It increases the efficiency of student for life. And it is because of that the student can go outside of school borders to environments that s/he can implement and try what s/he learns."

The statement of K39 about the suitability of out of school learning practices for Social Studies lesson, in fact contains many reasons single-handedly. K39 made supportive statements for the ones of K16 by saying that;

-"I believe that out of school education will be more successful than dusty, noisy classroom education under any circumstances. Because students including us get bored quicker indoor, this affects our learning. I think a beautiful garden will be more fun than classroom environment for both social sciences and math lessons accordingly this will be more productive. Especially if this lesson is Social Studies, I think there is no need to go back inside of the school."

- Obstacles in front of out of school learning environment

Table 4. Obstacles in front of out of school learning practices according to teacher candidates

\begin{tabular}{llcc}
\hline Category & Code & Frequency $(f)$ & Rate $(\%)$ \\
\hline & Economic reasons & 48 & 26.3 \\
& Reluctance of teacher and being unprepared & 35 & 19.2 \\
& The problem of getting a permit & 26 & 14.3 \\
& Transportation problem & 18 & 9.9 \\
& Safety worries & 16 & 8.8 \\
Obstacles & Excessive student number & 13 & 7.1 \\
& Time problem & 9 & 4.9 \\
& Reluctance of parents & 9 & 4.9 \\
& Other (density of curriculum, inapplicability of some subjects, space problem etc.) & 8 & 4.4 \\
Total & 182 & 100 \\
\hline
\end{tabular}

Answers were evaluated in Table 4 in general, According to this, teacher candidates see economic reasons (26.3\%), reluctance of teacher and teacher's being unprepared (19.2\%) and getting a permit (14.3\%) as the most important obstacles in front of out of school learning practices. Right along with these problems; transportation $(9.9 \%)$, safety $(8.8 \%)$, excessive student number (7.1\%), time insufficiency $(4.9 \%)$, reluctance of parents $(4.9 \%)$, density of curriculum, inapplicability of some subjects for this application, and space problems $(4.4 \%)$ are other obstacles stated by teacher candidates.

When these answers considered, it is seen that there are many obstacles in front of out of school learning applications from the point of teachers. The biggest obstacle is "economic reasons" with $26.3 \%$. In Turkey's economic condition, it is true that economic condition is the most important determiner in many subjects. With 
its developing country status, although Turkey transferred 8 times more resources to national education between 2002 and 2014, economic obstacles in front of out of school trip activities are seen as a problem. It is true that every out of school activity has a cozy, and it is seen as a problem also in developed countries (Little \& Lauver, 2005). When socio-economic situation was considered, it is not surprising for participant teacher candidates to put economic reasons to first rank. Statement made by teacher candidates K32 accordingly to this subject was given below;

-'I think the most important obstacle about this situation is that both schools and students do not have good financial situation. Both school and students do not have money. Unfortunately we know these kinds of situations quite well."

Similarly, K38 made a descriptive statement;

-"Economy, economy, economy. Even when we study at the university, we face the same problem. Almost everyone in the classroom has the same financial situation. Even now, when a trip is organized, many friends of ours cannot attend because of economic problems."

The statement of K38 is actually also a statement of another truth. Baykara and Pehlivan (2008) stated in their study that teachers are mostly from working or lower middle socio-economic levels. Hence, it is understandable for candidates in this situation to put economic reasons to the first rank. Except this problem, 19.2\% of teacher candidates stated that "reluctance of teacher and teacher's being unprepared" is also an obstacle for out of school practices. Statement made by K55, one of the teacher candidates accordingly to this subject was given below;

-'I know this from me and my siblings' teachers. Teachers do not want to take children outside of the school. They avoid the responsibility.

This obstacle for teachers corresponds to the statements of teachers in Table $6 \mathrm{~b}$ about their economic problems during their Bachelor's degree education. Indeed, we can show economic problems as one of the reasons of teacher's reluctance. K46, one of the teacher candidates stated that this situation discourages teachers for such applications, says that:

-'I think the reluctance of teachers is the biggest problem. But you also need to understand them. Because there are schools which cannot even afford their own costs, there are teachers that pay themselves for photocopies (like my father). While teachers cannot even gather 50 piastre for exam papers, they are right about being reluctant for going to trips. "

$14.3 \%$ of teacher candidates stated "getting permit" as an obstacle for out of school activities. Statement made by $\mathrm{K} 14$, one of the teacher candidates accordingly to this subject was given below:

-'I think some trip accidents that we see on Television frighten the teachers, parents and institutions. That is why getting an official permission is getting harder. In my opinion, getting an approval for permissions is not easy. Because it is a huge responsibility."

When media's special sensibility about such news considered, it is clear that this is a valid ground. Because of that victims of accidents, that occur during the trips, are students, society becomes more emotional about such news, which cause indignance, are discussed on media for days. Hence, both Ministry of National Education and parents and students have special sensibility for this subject.

-Out of school activities to be carried out

Table 5. Teacher candidates' out of school applications that they plan to do

\begin{tabular}{|c|c|c|c|}
\hline Category & Code & Frequency $(f)$ & Rate $(\%)$ \\
\hline \multirow{9}{*}{$\begin{array}{l}\text { Fields of } \\
\text { application }\end{array}$} & Museum tours & 61 & 37.4 \\
\hline & Trips to historical places & 52 & 32 \\
\hline & Natural and national parks, touristic places & 10 & 6.1 \\
\hline & School garden & 9 & 5.5 \\
\hline & Public enterprises and agencies & 9 & 5.5 \\
\hline & Religious places & 8 & 4.9 \\
\hline & Cinema/theatre & 7 & 4.3 \\
\hline & $\begin{array}{l}\text { Other (martyrdoms, NGO's, senior centers, libraries, traffic } \\
\text { education centers etc.) }\end{array}$ & 7 & 4.3 \\
\hline & Total & 163 & 100 \\
\hline
\end{tabular}


The answers given were evaluated in Table 5. According to this, when teacher candidates start their duties, it is seen that they plan to arrange museum tours at most (37.4\%) and visit historical places (32\%) from out-of-school applications. Apart from these, activities like trips to natural and national parks/touristic places $(6.1 \%)$, school gardens (5.5\%), public enterprises and agencies (5.5\%) etc. are among the activities that teacher candidates plan to do. This result overlaps with the data obtained from the question, "what comes into your mind when out-of-school environment is considered?". However, concepts of teacher candidates that they use to explain what out-of-school environments stand for them and the applications when they started their duties look similar. Apart from these, religious places (4.9\%), cinema/theatre (4.3\%), martyrdoms, dams, NGOs, senior centers, libraries, visit to traffic education centers are the activities that teacher candidates plan to carry out.

It is not surprising that they put the museum in the first place with $37.4 \%$ when teacher candidates' answers are examined. However, as it is seen in Table 2, they describe out-of-school learning with the most frequent "museum tours" with $34.9 \%$. Therefore, two relevant data of the study is in accordance with each other. Accordingly, K44 from teacher candidates making explanations made this statement:

-"When I become a teacher, I want to bring my students to the museums at most. There are museums in every city somehow. Also, we can find many appropriate materials for our subjects in these places".

Together with this, as out-of-school applications, $32 \%$ of teacher candidates as a result of their thought of "visiting historical places with the students", it is in accordance with the explanation that is defined as the most frequent with 27\% in Table 2. Therefore, $\mathrm{K} 45$ from teacher candidates making explanations made this statement:

-"These lands hosted very different and old civilizations. Many artifacts inherited from these still remain today. Thus, benefiting from these artifacts in our courses related directly to Social Sciences isn't useful for me but also for my students".

These two data are very important in terms of the fact that teacher candidates have awareness towards museums and historical places and they are intent on availability of these in social sciences course. Social sciences course should be carried out voluminously due to its historical subjects including visits to museums and historical places. We can say that it is the structure of this course's natural result that these environments, which offer a learning opportunity by discovering knowledge, ranked in the first place in the applications that teacher candidates planned to carry out.

In addition to this, subsequent to visit to museum and historical places based on tour observation, it is seen that the third most frequent activity to be carried out is "visit to natural and national parks/touristic places" with $6.1 \%$. Accordingly, K5 form teacher candidates making explanations came up with this statement:

-'In this subject, though the ones coming into the mind first are museums, mosques etc., natural parks, national parks or some other touristic places that we can benefit are also available. These especially attract my attention as well".

Their idea that the wealth Turkey has within this context is an opportunity for social sciences course/subjects is very important both for teacher candidates and their prospective students and also for Turkish education system. Because, it is known that how important visuality is in teaching of geographical subjects. Students' evaluations about the environment they live in and their absorptions by studying generally the whole Turkey with these field tours in its own place and their familiarization by living and feeling in this way are the factor both providing environment-human integration and also making learning as permanent by keeping it away from memorization.

-Out of school application in undergraduate education

Table 6a. Views of teacher candidates about sufficiency of out of school learning applications in undergraduate education

\begin{tabular}{llcc}
\hline Category & Code & Frequency $(f)$ & Rate $(\%)$ \\
\hline \multirow{4}{*}{ Sufficiency } & Sufficient & -- & -- \\
& Not sufficient & 73 & 100 \\
& Total & 73 & 100 \\
\hline
\end{tabular}

Answers were evaluated in Table 6a in general. According to this, it is seen that all of teacher candidates (100\%) claimed that they couldn't carry out these applications adequately during undergraduate education. Accordingly, statements of some of teacher candidates making explanations are given below; 
K34;

-"They talk about its benefits and the fact that we should do that when we become a teacher but they don't allow us to do. It is rather insufficient. Our teachers aren't very interested in going out school with us."

Other teacher candidate K22 stated;

-'Neither our teachers come to the class willingly, nor do they teach a lesson outside with us. Though there were many appropriate subjects for three years, we did not go outside of the school. If we had been, I would have remembered."

K35;

-'They talk about its benefits but none of the teacher taught a lesson like this except one or two. It is clear that they don't want to go outside the school. Therefore, the word of insufficient isn't enough."

These explanations are in accordance with Table 4. In Table 4, it is seen that unwillingness of teachers, which they mostly explained as a barrier, ranked in the second place about what barriers are in front of these applications. When it is considered in this context, it is seen that teachers in middle school and instructors in universities are against these applications in the same way and this situation causes dissatisfaction of teacher candidates. When it is supposed that the teachers teaching social sciences course went through the same process with these participants that will be teachers after some time, it is possible that this negative case can be seen for them when teacher candidates start their duties. However, explanation of K55 stating that he/she and his/her sibling had a problem about his/her teacher, which was evaluated under the theme of barriers in Table 4 , is remarkable.

Table $6 \mathrm{~b}$. Views of teacher candidates about reasons of insufficiency of out of school learning applications in undergraduate education

\begin{tabular}{llcc}
\hline Category & Code & Frequency $(f)$ & Rate $(\%)$ \\
\hline & Smooth instruction & 62 & 39 \\
& Insufficiency of time & 39 & 24.5 \\
& Economical reasons & 34 & 21.3 \\
Reasons of insufficiency & Inappropriateness of some course subjects & 12 & 7.5 \\
& City lived in & 12 & 7.5 \\
& Total & 159 & 100 \\
\hline
\end{tabular}

Given answers were evaluated in Table $6 \mathrm{~b}$ in general. According to this, teacher candidates show teacher's choosing to teach with smooth presentations appropriate for traditional education understanding $(39 \%)$ and their not giving importance to these applications as a reason for not carrying out of school activities in undergraduate education and inadequateness of time $(24.5 \%)$, economical reasons $(21.3 \%)$, inappropriateness of some courses/subjects (7.5\%) and city lived in (7.5\%) are shown among other reasons.

When the answers of teacher candidates are evaluated, it is seen that they explained the reasons of insufficiency of these applications carried out in undergraduate education as their teachers' not giving importance to these applications and their teaching through smooth presentation appropriate for traditional education understanding with \%39 as the most frequent. This answer also shows that constructive understanding isn't dominant in undergraduate education peculiar to working group of this research. Teaching lessons through smooth presentations is a huge contradiction in education faculties that are the institutions, which (should) plant the fact that behavioral approach isn't dominant in education world and education moves under the skin of constructivism and lessons should be taught within this direction. Accordingly, K17 from teacher candidates making explanations made this statement;

-"Teachers give much importance to learning through smooth presentation as it is easier and less tiring."

It is not fair to say that reasons of this unwillingness in university teachers are similar to the ones in teachers. Because, other basic duty of university teachers is to contribute his/her country and also the whole world in scientific field by publishing academic works apart from teaching lessons. For faculty members obtaining points to be an associate professor by publishing serious academic works, not only can it be a burden for them to attend at activities out of school, but also it can be hard for them to teach lessons. However, this does not mean that the lessons should be taught through smooth presentations. This reason also explains "time problem" that teacher candidates specified with $24.5 \%$ as the second most frequent reason. Accordingly, K45 from teacher candidates 
making explanations made this statement;

-"Teachers turn down offers on the grounds that they don't have any time."

The number of application to associate professorship increases parallel to increase in the number of publishing because of density of academic works rather than courses. In addition, YOK (Council of Higher Education) made the decision of letting the application of unsuccessful candidate after one year, which is cancelled by the Council of the State in order to prevent this increase. Together with this, $21.3 \%$ of teacher candidates show economical reasons that why out of school learning activities aren't carried out in undergraduate education. Accordingly, K22 from teacher candidates making explanations made this statement;

-"As students, we aren't willing to attend at out of city activities as they are expensive. However, activities in city are easier for us."

When this and other similar explanations are considered (K1, K19, K53, K66, K69), economical reasons result from teacher candidates. This situation, which is accepted as a barrier for expensive out of city tours, can't be in question for tours in city, where teaching is performed. Because, K9 from participants made this statement;

-"The biggest barrier is money problem for me and my friends. Not only out of school tours, but also the tours that we want to go with our friends aren't possible because of this. We can travel around the city we have education."

K50 explained this situation by saying;

-"Money is a very important reason. We can go everywhere if we have money. Otherwise - in fact we don't have - the farthest place we can go is Kastamonu Tower".

Economical reasons result from an important difference between these two environments (university/primary school) as one of the reasons why it is in the first place for middle school and in the third place for undergraduate education. Because, while an economical system is based on the parents in primary school, there is a free environment with free students working as part-time and getting a scholarship. Therefore, these two different environments are one of the situations explaining the difference between these two data.

\section{Discussion and Conclusion}

In order to determine ideas and thoughts of teacher candidates about out-of-school learning, the findings in this research are given below:

When the data obtained from the research are carefully examined, it is clear that the first activity that comes in to mind is museum tours and visits to historical places when it is said out-of-school learning environment for social sciences and form teacher candidates. These activities that will be evaluated in terms of tour observation are closely associated with structure/subjects of social sciences course. Availability of many instruments that can be related to especially history, geography and citizenship subjects make visits to significant places (tower, mountain, mosque, stream, government agencies) based on tour observation simply compulsory to make acquisitions about these more permanent. According to the result obtained from the study of Taylor et al. (2010), necessity of field work for students within this context is in accordance with this result.

All teacher candidates joining the research stated that social sciences course is appropriate for out-of-school environments. When subjects of history, geography and citizenship in the content of the courses are taken into consideration, it is seen that contexts of these disciplines cannot be limited to school/class environments. However, it is a compulsory principle to apply out-of-school learning environments in the curriculum to learn by experiencing and doing about many subjects from the structure and agencies of the government to our rights and responsibilities in citizenship education or museums, historical places/ruins in history and natural beauties and nature in geography. In this research, teacher candidates think that these applications are useful as they make the things learned in social sciences course more permanent and prepare students for real life and increase competences of individual against it. Together with this, in the studies by Fordham (2004), Little and Lauver (2005) and Çengelci (2013) students explained that these applications were positively welcomed by them and as a reason for this; out-of-school learning relaxed them, provided social environmental learning and stimulated independent learning. In addition, as it has an effect on student's reaching success, this draws attention as the other data of the study. Also, contributions of these activities appropriate for the subjects of social sciences to historical empathy and historical thinking abilities are the results obtained from the study (Marcus, 2007; Akyüz, 2009; Hooper-Greenhil, 1999; Coskun-Keskin \& Kaplan, 2012; Taylor et al., 2010; Y1lmaz \& Ege, 2015). In this study, it is clear that fieldwork and visits have positive effects on long-term memories of students, their self-respect, and creativity, feeling themselves, attention of learning and especially hyperactive children having 
lack of attention and their individual growth. Also, it is concluded that these applications make students and their curiosities alive and are good mechanisms for fighting against failures in education. The results obtained from aforementioned studies are in accordance with the findings of our research. Briefly, in accordance with the results of conducted scientific studies, teacher candidates are of the same opinion about the benefit of these applications for social sciences.

It is seen that teacher candidates joining the research stated that economical reasons, unwillingness of teacher and their extemporaneousness for this situation are the most encountered reasons in out-of-school learning applications. In addition to these, problem of permission, transformation/safety problems and excessive number of students are considered as other problems. When general economical status of students and problem of source in schools are taken into consideration, it is clear that these concerns are irrelevant (Topcu, 2013). Also when unwillingness of teachers, excessive number of students attending tours and the fact that this situation increases both responsibility and loss of time are considered, it becomes a situation that can be explained though there isn't any valid reason. Demirci (2009) states similar things about barriers in front of these applications. However, the reasons such as financial opportunities, time problem, official procedures, and density of course load; problems of completing curriculum and excessive student number and especially the fact that they didn't apply tour observation method are in accordance with the results obtained from other scientific studies (Cepni \& Aydin, 2015; Sagay, 2007; Mazman, 2007; Aktas, 2010; Ozur, 2010; Karakus et al., 2012; Memisoglu \& Öner, 2013; Topçu, 2013; Malkoc \& Kaya, 2015; Kaya, 2008). Tali \& Morag (2007) concluded that teachers didn't get prepared well and in spite of this, these tours are very beneficial for active learning, questioning and examining students. In addition to these problems, difficulty of permissions for out-of-city activities both from the management and the parents, transportation problem, safety concern, excessive number of students and unwillingness of parents due to economical concerns are showed as reasons why these applications can't be carried out efficiently. In Little and Lauver's (2005) study, similar results are obtained. According to the results obtained from this study, as barriers in front of these applications, dense programs of students, their family life and opportunities of family, the fact that the program is boring or interesting, problems of safety and transportation are shown. The results about barriers in front of out-of-school learning applications are in accordance with the findings of our research.

When teacher candidates joining the research start their duties, they claim that they want to carry out museum tours and visit historical places as out-of-school activities. The answers given to this question are in accordance with the answers asked to the question, "what comes into your mind when it is said out-of-school learning environments" in the first part of the research. However, while museum tours rank in the first place in two questions, visits to historical places rank in the next place. This result obtained from our research is in accordance with the findings of Cengelci (2013), Turkmen (2015) and Cepni and Aydin's (2015) study. However, participants put activities to be carried out to museum and historical places in the first places in all of these studies. Apart from these, visits to natural and touristic places, school yard, official institutions and agencies are the applications that they want to carry out. Briefly, it can be understood from given answers that teacher candidates want to actively use out-of-school learning applications when they start their duties.

Teacher candidates joining the research state that they could not apply enough out-of-school applications during their undergraduate study and as the most important reason of this, they claim that teacher gave more importance to education with presentation rather than teaching with these applications which nearly all of the participants (84.9\%) explained. Turkmen (2015) obtained similar result, which is in accordance with one of the results of our research. It is clear whether these applications are useful or not and also it is clear that theoretical instruction of these applications decreases efficiency while it should be instructed practically. Together with this, time problem and economical reasons are the other barriers that are in front of carrying out these applications. Also, though low in number, there are teacher candidates, who claim that the city of the university isn't appropriate enough for different activities as courses/subjects are and there aren't enough activities among the reasons.

When the data of the research are generally evaluated, it is seen that teacher candidates approach out-of-school learning environments and apply these in positive way. Within the context of these approaches, the structure and subjects of social sciences course overlap thoroughly and they offer supportive quality for each other. In constructivist education understanding, it is a fact that the student carries out learning by doing it actively and experiencing. When it is considered like this, making a course generally filled with theoretical knowledge like social sciences more enjoyable and amusing, therefore more permanent, is possible to make it a course that is learned by experiencing through such applications. Therefore, the things that the students saw on the pages of the books will be more permanent as they see them in real life outside the school.

As a result, it is clear that social sciences and form teacher candidates think that out-of-school learning 
environments are appropriate, necessary and therefore useful for teaching of social sciences course. It is a really positive situation that when they start their duties, teacher candidates plan to apply these applications largely in spite of many barriers, notably economical reasons, which they explained. Also, though social sciences and form teacher candidates are of the same opinion (positive) about these applications, it is a meaningful result that their teachers at the university, who taught them these are useful and necessary, didn't have them perform these applications sufficiently.

In accordance with the obtained results, these suggestions can be made:

- Financial support should be provided by ministry, local governments etc to eliminate these economic problems, stated by teacher candidates and many research, in front of out of school learning activities. For this, meetings for sponsorship with local firms or benefactors through directorates of national education can be beneficial. Thus, the fund problem can be eliminated.

- Formal procedures can be reduced for such activities, and necessary precautions need to be taken to make administrators and teachers feel more comfortable. Thereby, under the coordination of Ministry of National Education, activities can be organized as if they were mandatory elements of the curriculum, and by relieving the responsibility and fund problems of different schools from different economic levels, can cause the funds to be used more efficient.

- Academic members of Faculty of Education should give more importance to such activities. As a solution, it can be suggested for academic members of departments to collaborate both among themselves and with other academic members of different departments for this subject. Hence, both such activities will not be under the initiative of only academic members, and funds of faculty can be used more efficiently. Besides, planning activities of schools affiliated to the directorates of national education coordinately with Faculty of Education can also be a very useful solution. This may both increases the quality of the activity and combines financial and moral possibilities of universities with schools'.

- Further studies can research the reasons of why academic members carry out / do not carry out studies on out of school learning.

- Carrying out a similar study with teacher candidates from different departments can be beneficial, and a comparison can be made with different point of views for the same situation.

\section{References}

Aktaş. S. (2010). Illköğretim II. kademe sosyal bilgiler derslerinde coğrafya konularının öğretimi: sorunlar ve çözüm önerileri (Yüksek lisans tezi, Kilis 7 Aralık Üniversitesi, Sosyal Bilimler Enstitüsü, Kilis). Retrieved from https://tez.yok.gov.tr/UlusalTezMerkezi

Aktekin, S. (2006). Tarih öğretmenlerinin gözüyle tarih derslerinde yerel tarih. Toplumsal tarih, S. 149. İstanbul: Toplumsal Tarih Vakfi.

Aktekin, S. (2010). Ortaöğretim tarih eğitiminde yerel tarihin yeri ve önemi. Eğitimde ve Uygulama, 6(1), 86-105.

Akyüz, G. (2009). Sanayi müzelerinin tarih eğitiminde kullanım durumu: Rahmi M. Koç müzesi örneği (Yüksek lisans tezi, Marmara Üniversitesi, Eğitim Bilimleri Enstitüsü, İstanbul). Retrieved from https://tez.yok.gov.tr/UlusalTezMerkezi

Aladag, E., Akkaya, D., \& Şensöz, G. (2014). Sosyal bilgiler öğretiminde sanal müze kullanımının öğretmen görüşlerine göre değerlendirilmesi. Trakya Üniversitesi Sosyal Bilimler Dergisi, 16(2), 199-217.

Ata, B. (2002). Müzelerde ve tarihi mekânlarla tarih ögrretimi: Tarih ögretmenlerinin "müze eğitimine” ilişkin görüşleri (Doktora tezi, Gazi Üniversitesi, Sosyal Bilimler Enstitüsü, Ankara). Retrieved from https://tez.yok.gov.tr/UlusalTezMerkezi

Avc1-Akçalı, A., \& Aslan, E. (2012). Tarih öğretiminin iyileştirilmesi yolunda alternatif bir yöntem: Sözlü tarih. Kastamonu Eğitim Dergisi, 20(2), 669-668

Balc1, A. (2004). Sosyal bilimlerde araştırma yöntem teknik ve ilkeler (4th ed.). Ankara: Pegem A.

Barnes, A., \& Laird, C. (2012). The effects of social media on children. Retrieved from http://sites.ewu.edu/cmst496-stafford/2012/06/06/the-effects-of-social-media-on-children

Basu, P., \& Coleman, S. (2010). Culture, 1dentity, difference: developing a museum-based anthropology education resource for pre-university students. Anthropology in Action, 17(2\&3), 87-104. https://doi.org/10.3167/aia.2010.170208 
Baykara-Pehlivan, K. (2008). Sınıf öğretmeni adaylarının sosyo-kültürel özellikleri ve öğretmenlik mesleğine yönelik tutumları üzerine bir çalışma. Mersin Üniversitesi Eğitim Fakültesi Dergisi, 4(2), 151-168.

Bozdoğan, A. E., \& Yalçın, N. (2006). Bilim merkezlerinin ilköğretim öğrencilerinin fen'e karşı ilgi düzeylerinin değişmesine ve akademik başarısına etkisi: Enerji parkı. Ege Eğitim Dergisi, 2(7), 95-114.

Bunting, C. J. (2006). Interdisciplinary teaching through outdoor education. Champaign. IL: Human Kinetics

Çavus, R., Umdu-Topsakal, Ü., \& Öztuna-Kaplan, A. (2014). İnformal öğrenme ortamlarının çevre bilinci kazandırmasına ilişkin öğretmen görüşleri: Kocaeli bilgievleri Örneği. Pegem Eğitim ve Öğretim Dergisi, $3(1), 15-26$.

Çengelci, T. (2013). Sosyal bilgiler öğretmenlerinin sınıf dış1 öğrenmeye ilişkin görüşleri. Kuram ve Uygulamada Eğitim Bilimleri Educational Sciences: Theory \& Practice, 13(3), 1823-1841.

Çepni, O., \& Aydın, F. (2015). Sosyal bilgiler öğretmenlerinin sınıf dışı okul ortamlarına ilişkin görüşleri. The Journal of Academic Social Science Studies, 39, 317-335. https://doi.org/10.9761/JASSS3061

Coşkun-Keskin, S., \& Kaplan, E. (2012). Sosyal bilgiler ve tarih eğitiminde okul dışı öğrenme ortamı olarak oyuncak müzeleri. Elektronik Sosyal Bilimler Dergisi, 11(41), 95-115.

Çulha, B. (2006). Tarihsel mekânlarda keşfederek öğrenme yoluyla sosyal bilgiler öğretimine yönelik öğrenci görüşleri (Yüksek lisans tezi, Dokuz Eylül Üniversitesi, Eğitim Bilimleri Enstitüsü, İzmir). Retrieved from https://tez.yok.gov.tr/UlusalTezMerkezi

Danacıoğlu, E. (2001). Geçmişin izleri, yanıbaşımızdaki tarih için bir kılavuz. İstanbul: Tarih vakfı yurt.

Demirboğa, E. (2010). Sanal müze ziyaretlerinin öğrencilerin bilişsel ve duyuşsal kazanımları üzerindeki etkileri (Yüksek lisans tezi, Gazi Üniversitesi, Eğitim Bilimleri Enstitüsü, Ankara). Retrieved from https://tez.yok.gov.tr/UlusalTezMerkezi

Demirci, M. T. (2009). Kültürel öğelerin ögrretiminde müze gezilerinin önemi (Yüksek lisans tezi. Selçuk Üniversitesi, Sosyal Bilimler Enstitüsü, Konya). Retrieved from https://tez.yok.gov.tr/UlusalTezMerkezi

Dönmez, C. (2009). Sosyal bilgiler derslerinde tarihi mekânların kullanımının öğrenci görüşleri çerçevesinde değerlendirilmesi. In E. Ö. Yiğit (Ed.), IV. Sosyal Bilimler Eğitimi Kongresi içinde (pp. 656-666). İstanbul: Marmara Üniversitesi.

Dubow, E. F., Huesmann, L. R., \& Greenwood, D. (2006). Media and Youth Socialization (pp. 404-437). Retrieved from http://www.rcgd.isr.umich.edu/aggr/articles/Huesmann/2006.Dubow_etal.Media\&Youth Socialization.inHandbkofSocialization.pdf

Durmuş, S. H. (2007). Oyunlarla doğa eğitimi. Ekoloji magazin dergisi, 15.

Ermiş, B. (2010). İlköğretim 6. sinıf ögrrencilerinin görsel sanatlar dersinde "üç boyutlu sanal müze ziyareti" etkinliğine ilişskin görüşleri (Yüksek lisans tezi, Gazi Üniversitesi, Eğitim Bilimleri Enstitüsü. Ankara). Retrieved from https://tez.yok.gov.tr/UlusalTezMerkezi

Ertaş, H. (2012). Okul dışı etkinliklerle desteklenen eleştirel düşünme öğretiminin, eleştirel düşünme eğilimine ve fizik dersine yönelik tutuma etkisi (Doktora tezi, Hacettepe Üniversitesi, Fen Bilimleri Enstitüsü, Ankara). Retrieved from https://tez.yok.gov.tr/UlusalTezMerkezi

Filiz, N. (2010). Sosyal bilgiler öğretiminde müze kullanımı (Yüksek lisans tezi, Marmara Üniversitesi, Eğitim Bilimleri Enstitüsü, İstanbul). Retrieved from https://tez.yok.gov.tr/UlusalTezMerkezi

Ford, P. (1986). Outdoor education: Definition and philosophy. ED 267 941. Retrieved from http://www.eric.ed.gov/PDFS/ED267941.pdf

Fordham, I. (2004). Out-of-school-hours learning in the United Kingdom. New directions for youth development. No. 101. https://doi.org/10.1002/yd.72

Goessl, L. (2010). How does Social Networking Affect Socialization. Retrieved from http://www.sciences360.com/index.php/how-does-social-networking-affect-socialization-2-8428/

Hooper-Greenhill, E. (1999). Müze ve galeri eğitimi. (Çev. M. Örge Evren. E. G. Kapçı). Ankara: Ankara Üniversitesi Çocuk Kültürü Araştırma ve Uygulama Merkezi Yayınları.

Işık, H. (2008). İlköğretimde tarih konularının yerel tarih ile ilişkilendirilmesinin öğrenci başarısına etkisi. Uluslararası Sosyal Araştırmalar Dergisi, 1(4), 290-310.

Karadeniz, O., \& Ata, B. (2013). Sosyal bilgiler dersinde proje fuarının kullanılmasına ilişkin öğrenci görüşleri. 
Adlyaman Üniversitesi Sosyal Bilimler Enstitüsü $\quad$ Dergisi, 6(14), 375-410. https://doi.org/10.14520/adyusbd.607

Karadeniz, C., \& Okvuran, A. (2014). Müzede bir gece: Ankara üniversitesi öğrencileri ile çorum arkeoloji müzesi'nde müze eğitimi. Elementary Education Online, 13(3), 865-879.

Karakuş, U., Aksoy, B., \& Gündüz, İ. (2012). Dokuzuncu sınıf coğrafya derslerinde ders dışı etkinliklerin öğretmen görüşlerine göre değerlendirilmesi. GEFAD/GUJGEF, 32(2), 489-513.

Kaya, B. (2008). Oluşturmacı Yaklaşıma Göre Düzenlenen Illköğretim TC. Inkılâp Tarihi ve Atatürkçülük Dersinin Tarihsel Öğrenmeye Etkisi: Bir Eylem Araştırması (Yayımlanmamış doktora tezi, Marmara Üniversitesi, Sosyal Bilimler Enstitüsü)

Lakin, L. (2006). Science beyond the classroom. Journal of Biological Education, 40(2), 89-90.

Little, P., \& Lauver, S. (2005). Engaging adolescents in out-of-school time programs: Learning what works. The prevention researcher, $12(2), 7-10$.

Malkoç, S., \& Kaya, E. (2015). Sosyal bilgiler öğretiminde sınıf dışı okul ortamlarının kullanımı. Elementary Education Online, 14(3). 1079-1095. https://doi.org/10.17051/io.2015.40410

Marcus, A. S. (2007). Representing the past and reflecting the present: museums. memorials. and the secondary history classroom. Social Studies, 98(3), 105-110.

Mazman, F. (2007). Sosyal Bilgiler Eğitiminde Gezi Gözlem Metodunun Uygulanmasına İlişkin Bir Araştırma (Yüksek lisans tezi, Gazi Osman Paşa Üniversitesi, Sosyal Bilimler Enstitüsü, Tokat). Retrieved from https://tez.yok.gov.tr/UlusalTezMerkezi

Memişoğlu, H., \& Öner, G. (2013). Sosyal bilgiler dersinde öğrenci ve öğretmen görüşlerine göre coğrafya konularının öğretimi. Journal of Research in Education and Teaching, 2(3), 40.

Meydan, A.,\& Akkuş, A. (2014). Sosyal bilgiler öğretiminde müze gezilerinin tarihi ve kültürel değerlerin kazandırılmasındaki önemi. Marmara Coğrafya Dergisi, 29, 402-422.

Meydan, A. (2009). Sosyal bilgiler öğretiminde gezi-gözlem ve doğa eğitimi. In R. Turan, A. M. Sünbül, \& H. Akdağ (Eds.), Sosyal Bilgiler öğretiminde Yeni Yaklaşımlar I (pp. 241-262). https://doi.org/10.14781/mcd.92390

Miles, B. M., \& Huberman, A. M. (2015). Nitel Veri Analizi (Çev. Ed. Sadegül Akbaba Altun, Ali Ersoy). Ankara: Pegem Akademi.

Okur-Berberoğlu, E., \& Uygun, S. (2013). Sınıfdışı eğitimin dünyadaki ve Türkiye'deki gelişiminin incelenmesi. Mersin Üniversitesi Ĕ̈itim Fakültesi Dergisi, 2(9), 32-42.

Öner, G. (2015). Sosyal bilgiler öğretmenlerinin ‘okul dışı tarih öğretimi’ne ilişkin görüşlerinin incelenmesi. TUHED Turkish History Education Journal, 4(1), 89-121.

Özgen, N. (2011). Fiziki coğrafya dersi öğretim metoduna farklı bir yaklaşım: gezi-gözlem destekli öğretim. Marmara Coğrafya Dergisi, 23, 373-388.

Özür, N. (2010). Sosyal bilgiler dersinde sınıf dışı etkinliklerin öğrenci başarısına etkisi (Doktora tezi, Gazi Üniversitesi, Eğitim Bilimleri Enstitüsü, Ankara). Retrieved from https://tez.yok.gov.tr/UlusalTezMerkezi

Patton, M. Q. (2014). Nitel araştırma ve değerlendirme yöntemleri (3rd ed.). (Çev. Ed. Mesut Bütün. Selçuk Beşir Demir). Ankara: Pegem Akademi.

Rosen, L. (2011). Social networking's good and bad impacts on kids. Retrieved from http:/www.apa.org/news/press/releases/2011/08/social-kids.aspx

Safran, M., \& Ata, B. (1998). Okul dışı tarih öğretimi. Gazi Üniversitesi Ĕ̆itim Fakültesi Dergisi, 18(1), 87-94.

Sagay, N. (2007). İlköğretim II. kademe sosyal bilgiler derslerinde coğrafya konularının ögretimi: problemler ve öneriler (Yüksek lisans tezi, Afyon Kocatepe Üniversitesi, Sosyal Bilimler Enstitüsü, Afyonkarahisar). Retrieved from https://tez.yok.gov.tr/UlusalTezMerkezi

Şahenk-Erkan, S. S. (2013). Türkiye-Fransa ilköğretim eğitim sistemlerinin ve ingilizce ders programlarının karşılaştırılması. Turkish Studies - International Periodical for the Languages. Literature and History of Turkish or Turkic, 8(8), 1207-1221. https://doi.org/10.7827/turkishstudies.5197

Sarı, İ. (2007). Sosyal bilgiler ögretiminde sözlü tarih etkinliklerinin ögrrenci başarı, beceri ve tutumlarına etkisi (Doktora tezi, Gazi Üniversitesi, Eğitim Bilimleri Enstitüsü, Ankara). Retrieved from 
https://tez.yok.gov.tr/UlusalTezMerkezi

Şimşek, A., \& Kaymakçı, S. (Ed.). (2015). Okul dışı sosyal bilgiler öğretimi. Ankara: Pegem akademi.

Stemler, S. (2001). An overview of content analysis. Practical Assessment, Research \& Evaluation, 7(17).

Stollak, M., Vandenberg, A., Zeni, J., \& Scribner, K. J. (2014). The impact of social media policies on the staffing and socialization process. Retrieved from http://www.aabri.com/OC2012Manuscripts/OC12041.pdf

Tali, T., \& Morag, O. (2007). School visits to natural history museums: Teaching or enriching? Journal of research in science teaching, 44(5), 747-769. https://doi.org/10.1002/tea.20184

Tatar, N., \& Bağrıyanık, K. E. (2012). Opinions of science and technology teachers about outdoor education. Elementary Education Online, 11(4), 883-896.

Taylor, C., Power, S., \& Rees, G. (2010). Out-of-school learning: the uneven distribution of school provision and local authority support. British Educational Research Journal, 36(6), 1017-1036. https://doi.org/10.1080/01411920903342046

Topçu, E. (2013). Sosyal bilgiler dersinde coğrafya kazanımlarının gerçekleştirilmesinde öğretmenlerin tercih ettiği yöntemler. Marmara Coğrafya Dergisi, 28, 331-369.

Tosun, O. S. (2009). Müze incelemelerinin ilköğretim okullarındaki görsel sanatlar eğitimine .katkısı (Bolu ili örneği) (Yüksek lisans tezi, Dokuz Eylül Üniversitesi, Eğitim Bilimleri Enstitüsü, İzmir). Retrieved from https://tez.yok.gov.tr/UlusalTezMerkezi

Tunç-Şahin, C. (2011). Yerel tarih uygulamalarının başarıya ve öğrenci ürünlerine etkisi. Uluslararası Sosyal Araştırmalar Dergisi, 4(169), 453-462.

Türkmen, H. (2010). İnformal (sınıf-dışı) Fen bilgisi eğitimine tarihsel bakış ve eğitimimize entegrasyonu. Çukurova Üniversitesi Eğitim Fakültesi Dergisi, 39(03), 46-59.

Ustaoğlu, A. (2012). Illköğretim 7. sinıf sosyal bilgiler dersi türk tarihinde yolculuk ünitesinde sanal müzelerin kullanımının ögrrenci başarısına etkisi (Yüksek lisans tezi, Gazi Üniversitesi, Eğitim Bilimleri Enstitüsü, Ankara). Retrieved from https://tez.yok.gov.tr/UlusalTezMerkezi

Utku, Ç. (2008). İlköğretim 5. sınıf düzeyi sanat eğitiminde, müze eğitiminin ögrencilerin tutumlarına etkisi (Yüksek lisans tezi, Gazi Üniversitesi, Eğitim Bilimleri Ens titüsü, Ankara). Retrieved from https://tez.yok.gov.tr/UlusalTezMerkezi

Yapıc1, N. (1995). İlkokullarda ögretmen, ögrenci ve velilerin ev ödevi konusundaki görüşlerinin belirlenmesi (Yüksek lisans tezi, Ankara Üniversitesi, Sosyal Bilimler Enstitüsü, Ankara).

Yeşilbursa, C. C. (2008). Sosyal bilgiler öğretiminde tarihi yerlerin kullanımı. TÜBAR, XXIII, 220.

Yıldırım, A., \& Şimşek, H. (2005). Sosyal Bilimlerde Nitel Araştırma Yöntemleri (5th ed.). Ankara: Seçkin.

Yıldırım,T., \& Tahiroğlu, M. (2012). Sanal ortamda gerçekleştirilen müze gezilerinin ilköğretim öğrencilerinin sosyal bilgiler dersine yönelik tutumlarına etkisi. Elektronik Sosyal Bilimler Dergisi, Cilt:11, 39(11), 104-114.

Yılmaz, A., \& Egüz, Ş. (2015). Tarih ve sosyal bilgiler öğretmen adaylarının tarih öğretiminde müzenin önemi hakkındaki tecrübe ve düşünceleri. Turkish Studies International Periodical for the Languages. Literature and History of Turkish or Turkic, 10/11, 1637-1650. https://doi.org/10.7827/TurkishStudies.8596

Yılmaz, K., \& Şeker, M. (2011). İlköğretim öğrencilerinin müze gezilerine ve müzelerin sosyal bilgiler öğretiminde kullanılmasına ilişkin görüşlerinin incelenmesi. İstanbul Aydın Üniversitesi Dergisi, 9, 21-39.

\section{Note}

Note 1 . The reason why candidate Primary School teachers also participated in this study is about the education of Social Science in Turkey. In Turkish education system, Social Sciences course is in the curriculum of 4th, 5th, 6th, and 7th grades. Therefore in primary school, the course was given by Primary School teachers. 


\section{Copyrights}

Copyright for this article is retained by the author(s), with first publication rights granted to the journal.

This is an open-access article distributed under the terms and conditions of the Creative Commons Attribution license (http://creativecommons.org/licenses/by/4.0/). 